Review Article

\title{
The Therapeutic Prospects of Naturally Occurring and Synthetic Indole Alkaloids for Depression and Anxiety Disorders
}

\author{
Samman Munir $\mathbb{D}^{1},{ }^{1}$ Aqsa Shahid $\mathbb{D}^{2}{ }^{2}$ Bilal Aslam, ${ }^{2}$ Usman Ali Ashfaq ${ }^{(D)}{ }^{1}$ \\ Muhammad Sajid Hamid Akash, ${ }^{3}$ Muhammad Akhtar Ali, ${ }^{4}$ Ahmad Almatroudi ${ }^{\circ},{ }^{5}$ \\ Khaled S. Allemailem $\mathbb{D}^{5}{ }^{5}$ Muhammad Shahid Riaz Rajoka, ${ }^{6}$ and Mohsin Khurshid $\mathbb{D}^{2}$ \\ ${ }^{1}$ Department of Bioinformatics and Biotechnology, Government College University, Faisalabad, Pakistan \\ ${ }^{2}$ Department of Microbiology, Government College University, Faisalabad, Pakistan \\ ${ }^{3}$ Department of Pharmaceutical Chemistry, Government College University, Faisalabad, Pakistan \\ ${ }^{4}$ School of Biological Sciences, University of the Punjab, Lahore, Pakistan \\ ${ }^{5}$ Department of Medical Laboratories, College of Applied Medical Sciences, Qassim University, Buraydah, Saudi Arabia \\ ${ }^{6}$ College of Chemistry and Environmental Engineering, Shenzhen University, Shenzhen 518060, Guangdong, China
}

Correspondence should be addressed to Mohsin Khurshid; mohsin.mic@gmail.com

Received 13 August 2020; Revised 10 September 2020; Accepted 21 September 2020; Published 16 October 2020

Academic Editor: Zulqarnain Baloch

Copyright (C) 2020 Samman Munir et al. This is an open access article distributed under the Creative Commons Attribution License, which permits unrestricted use, distribution, and reproduction in any medium, provided the original work is properly cited.

\begin{abstract}
Depression and anxiety are the most common disorders among all age groups. Several antidepressant drugs including benzodiazepine, antidepressant tricyclics, azapirone, noradrenaline reuptake inhibitors, serotonin selective reuptake inhibitors, serotonin, noradrenaline reuptake inhibitors, and monoamine oxidase inhibitors have been used to treat these psychiatric disorders. However, these antidepressants are generally synthetic agents and can cause a wide range of side effects. The potential efficacy of plant-derived alkaloids has been reviewed against various neurodegenerative diseases including Alzheimer's disease, Huntington disease, Parkinson's disease, schizophrenia, and epilepsy. However, data correlating the indole alkaloids and antidepressant activity are limited. Natural products, especially plants and the marine environment, are rich sources of potential new drugs. Plants possess a variety of indole alkaloids, and compounds that have an indole moiety are related to serotonin, which is a neurotransmitter that regulates brain function and cognition, which in turn alleviates anxiety, and ensures a good mood and happiness. The present review is a summary of the bioactive compounds from plants and marine sources that contain the indole moiety, which can serve as potent antidepressants. The prospects of naturally occurring as well as synthetic indole alkaloids for the amelioration of anxiety and depression-related disorders, structure-activity relationship, and their therapeutic prospects have been discussed.
\end{abstract}

\section{Introduction}

Depression is a common mental problem that affects an estimated 264 million people globally [1]. The main symptoms include the inability to experience interest and pleasure, self-doubt, loss of concentration, social anxiety, appetite, and sleep disorder [2]. Certain chemicals or hormonal imbalances, for example, serotonin, in the brain is considered as the causal factor for depression. Besides, hormones such as dopamine and norepinephrine can also contribute to depression as the optimum concentrations of these hormones are essential for brain physiology and to control one's feelings [3].

For the treatment of depression, the choice of psychotherapy and medications depends on the severity of the symptoms. Antidepressant drugs are of various types; they differ in their mechanisms of action, side effects, and cost. The first-line treatment for depression may include either a selective serotonin reuptake inhibitor (SSRI) or a tricyclic antidepressant (TCA) [4]. Although several antidepressant 
formulations are available in the market for the therapeutic management of depression, the majority of them have a wide range of side effects [5]. Therefore, the use of herbal extracts in their crude from or a semi-purified form is gaining ground among clinicians as well as patients as an alternative therapy for depressive disorders $[6,7]$.

The data regarding the mechanism of action of phytochemicals on the central nervous system (CNS) for the amelioration of depressive disorders are limited. The studies have discussed the relationship between the structure of the flavonoids isolated from natural and synthetic sources and antidepressant activity. The overall activity and the potential use of synthetic indole alkaloids (IAs) in medicine have also been described in various studies $[8,9]$. However, studies on the antidepressant potential of indole alkaloids from plants or other natural sources are scarce. In this review, we have discussed the potential of indole alkaloids from plants and of marine origin as well as synthetic indole alkaloids for the treatment of depression and anxiety. Moreover, the structure, activity, potential targets, and sources of indole alkaloids have also been discussed.

\section{Structure and Function of Indole Alkaloids}

Indole alkaloids (IAs) are bicyclic compounds with a 6membered benzene ring that is fused to a 5 -membered pyrrole ring. The presence of nitrogen atom in the pyrrole ring leads to the basic characteristics of IAs making them pharmacologically active [9]. IAs are widely found in various plant families like Loganiaceae, Nyssaceae, Apocynaceae, and Rubiaceae. Major IAs that are extracted from plants involve the potent antitumor drugs, vincristine, and vinblastine, from the species Catharanthus roseus, and the antihypertensive agent, reserpine, from the species Rauvolfia serpentine [10,11]. Studies reporting the use of IAs in the treatment of depression have been carried out since 1952; however, not enough attention has been paid by the researcher community toward the therapeutic benefits of plants, especially the antidepressant potential.

IAs are usually involved in the functioning of $\mathrm{G}$ proteincoupled receptors (GPCRs), particularly in neuronal transmission using the 5-hydroxytryptamine/HT (serotonin) receptors. In addition to donating hydrogen bond through free nitrogen-hydrogen, the density of pi-electrons also facilitates the highest energy molecular orbital of the indole skeleton, which enables the interaction with nitrogen bases, specifically target proteins and protonated atoms [8]. The $\mathrm{N}$-atom present within the indole ring maintains the aromaticity and makes the $\mathrm{NH}$ binding acidic instead of nitrogen basic. This indole moiety is capable of forming $\mathrm{H}$-bonds via pi-pi stacking, $\mathrm{NH}$ moiety, or cation-pi interactions, through the aromatic moieties [12]. The hydrophobicity of indole moieties is almost equal to the phenyl ring and less than the classical isosteric benzofuran and the benzothiophene group. The $\mathrm{NH}$ group of indole has a key role in interacting with the target bioreceptor, whereas the synthesized benzofuran and benzothiophene derivatives show mild-to-moderate affinity toward the targeted bioreceptor [8]. Reserpine is an example of IAs obtained in the past sixty years which exhibits a sedative effect on the central nervous system (CNS). Furthermore, two chemicals, i.e., serotonin and tryptamine are also derivatives of indole alkaloids and are found within the brain.

\section{The Indole Ring in Drugs}

The indole ring is found in many drugs that are available in the market. Many of these belong to a group of triptan drugs that are utilized for relieving migraine and headaches. All members of the triptan class are considered to be the agonists of the migraine-associated $5 \mathrm{HT}_{1 \mathrm{D}}$ and $5 \mathrm{HT}_{1 \mathrm{~B}}$ serotonin receptors. Imitrex (Sumatriptan) was formulated by GlaxoSmithKline for treating migraine and was the first triptan member to be introduced in the market $[13,14]$. In comparison to the 2nd generation triptans, Imitrex has a relatively short half-life and low oral bioavailability. Frovatriptan (Frova), formulated by Vernalis, is used for treating menstrual migraine headaches. The affinity of frovatriptan toward the migraine-specific $5 \mathrm{HT}_{1 \mathrm{~B}}$ receptors is found to be greater than all triptans [15]. Moreover, frovatriptan can also bind to the receptors of $5 \mathrm{HT}_{7}$ and $5 \mathrm{HT}_{1 \mathrm{D}}$ subtypes [16, 17]. Zolmitriptan (Zomig) commercialized by AstraZeneca is used for the treatment of cluster headaches and acute migraine. Naratriptan has also been used for the management of migraine headaches, and its adverse reactions include tiredness, dry mouth, tingly feet or hands, and dizziness. All these available triptan drugs are highly effective and well-tolerated [18]. The highest prevalence of CNS-associated side effects, i.e., drowsiness and dizziness, have been reported for rizatriptan $(10 \mathrm{mg})$, eletriptan $(80 \mathrm{mg}$, $40 \mathrm{mg}$ ), and Zomig (5 mg) [19]. The differences observed in the adverse events for triptan drugs are probably not due to their different binding affinity toward neurological receptors or serotonin receptors within the CNS. There is a positive association between the adverse effects of CNS and the lipophilicity coefficient; these unwanted effects depend on the concentration and dosage.

The indole moiety is also called bioisosteres as it has physical and chemical properties akin to other biological molecules. The similarity has been used in prototype drug development, which aimed at improving the pharmacological activity as well as the pharmacokinetic (PK) profile. In a study, the pharmacological evaluation of thienopyrrole and benzo[b]furans resulted in bioisosteric molecules having dimethyltryptamine (DMT)-like effect. The initial work with 3-indenalalkylamines and benzo[b]thiophenes revealed that in the compounds that lack a ring substituent, their ability to act as agonists in rat fundus is almost like the tryptamines. The findings demonstrated that indole $\mathrm{N}-\mathrm{H}$ is not essential for activating the serotonin (5-HT2) receptor in rat fundus [20].

\section{Serotonin Receptors as Potential Targets for Neurologically Active IAs}

Considering that depression affects almost 18 million Americans every year, it is critical to design new and effective medications to counter it. Intensive investigations have been 
carried out in the field of novel target identification for antidepressant therapies; however, the majority of antidepressants still target different neurotransmitters, primarily dopamine, noradrenaline, and serotonin [21, 22].

Serotonin, a neurotransmitter that is found in the peripheral and central nervous system, plays a crucial role in the functioning of the normal brain as well as the regulation of mood, sleep, memory, appetite, anxiety, sexual function, and several others [23]. Serotonin functions through seven different receptor families, viz., 5-HT1-5-HT7, which are subdivided into various classes. Excluding the receptor 5HT3, which belongs to a superfamily of ligand-gated ion channel (LGIC), all 5-HT receptors are a group of GPCR families. Owing to the absence of selective ligands, still little is known about numerous subclasses of serotonin receptors $[24,25]$. However, structural similarity between the exogenous agonists of IAs and endogenous neurotransmitters, for example, serotonin, has driven the researchers to determine the probable neurological effect of these potent molecules.

\section{Medicinal Plants: New Leads for the Development of Antidepressant Drugs}

It seems that presently the patients are increasingly dependent on synthetic drugs for the amelioration of emotional disorders. However, the studies have indicated that the use of herbal products for the management of psychiatric disorders has also gained importance. Recent scientific studies have focused on the confirmation of the supposedly psychoactive properties of medicinal plants. The phytochemical screening of plants is a multistep process that includes fractionation, purification, isolation, chemical elucidation of phytoconstituents, and the pharmacological studies, as shown in Figure 1.

The researchers have isolated various compounds acting on the CNS from different plants, which have been used clinically in their natural or modified form or are being tested in preclinical and clinical trials, as shown in Table 1.

5.1. Passiflora incarnata. P. incarnata along with other species, e.g., $P$. alata, $P$. edulis, and P. caerulea, have been widely utilized in traditional treatments as a sedative in the United States and some European countries [49]. The chemical structure of benzos (benzodiazepines) drugs contains the fusion of a benzene ring and a diazepine ring, with a 7-membered heterocyclic ring having two $\mathrm{N}$-atoms. IAs obtained from Passiflora incarnata, viz., harmine, harmol, harmalol, harmaline, and harman, also contain a benzene ring that is fused to a 5-membered heterocyclic ring comprising one $\mathrm{N}$-atom. Various studies have demonstrated that Passiflora incarnata possesses a pharmacological activity much like benzos and functions via receptors of $\gamma$-aminobutyric acid [50].

5.2. Mitragyna speciosa. The leaves or extracts of kratom (Mitragyna speciosa) have been commonly used in traditional medicines for the improvement of blood circulation and the treatment of diabetes and diarrhea [51]. Mitragynine is an important indole alkaloid found in kratom and its analogs, paynantheine, speciociliatine, and speciogynine [52]. Two experiments performed on the alkaloid and the aqueous extracts of kratom produced the effect of antidepressants during behavioral despair tests on animal models [53]. A study carried out on mitragynine exhibited an antidepressant-like effect in behavioral animal models of depression by interacting with the hypothalamic-pituitary-adrenal (HTPA) axis within the endocrine system [54].

5.3. Peganum harmala. P. harmala has been used in traditional medicine in different societies for the treatment of certain nervous system disorders and psychiatric conditions such as Parkinson's disease and nervousness and to relieve severe pain [55-58]. The alkaloids obtained from $P$. harmala were found to be psychoactive, and different studies in animal models have indicated a wide range of effects such as hallucination, analgesia, excitation, and antidepressant effect produced by the active alkaloids of P. harmala [59-62]. Harmine, harmaline, and norharmane are the alkaloids found in P. harmala, which are also present in the body. However, in certain patients and conditions such as Parkinson's disease, drug addicts, alcoholics, and smokers, the high concentration of these alkaloids have been found; therefore, it is believed that these alkaloids play an important role in various CNS problems [63].

Studies have shown that beta-carbolines derived from P. harmala can interact with dopamine, opioid, 5-hydroxytryptamine, Gamma-aminobutyric acid (GABA), imidazoline, and benzodiazepine receptors on the nervous system, thereby exerting various pharmacological effects $[58,62,64,65]$. Furthermore, these alkaloids were found to inhibit monoamine oxidase and have shown neuroprotective activity. This significant feature makes them a choice for the treatment of anxiety and depressive disorders $[60,65,66]$.

5.4. Piper methysticum. Piper methysticum is used as a beverage named kava, which gives a happy state of mind while decreasing anxiety and fatigue [67]. The investigation revealed that most pharmacological effects were associated with the use of kava resin (lipid extract) rather than the aqueous extract. Seven pyrones, known as kavalactone, are present in the kava resin. These kavalactones usually interact with the serotonin, glutamatergic neurotransmitters, GABA, dopaminergic pathways; inhibit monoamine oxidase (MAO)-B; and exert various effects on several ion channels [68]. Dihydromethysticin (DHM) is a major kavalactone present in the roots of the kava plant. The chemical structure of the DHM consists of arylethylene-alpha-pyrone, which is linked to an indole moiety containing two oxygen atoms instead of nitrogen atoms. This facilitates an anxiolytic effect and serves as an antidepressant medicine. Double-blind, placebo-controlled investigations revealed that kavalactone compounds exert antianxiety activities without decreasing 


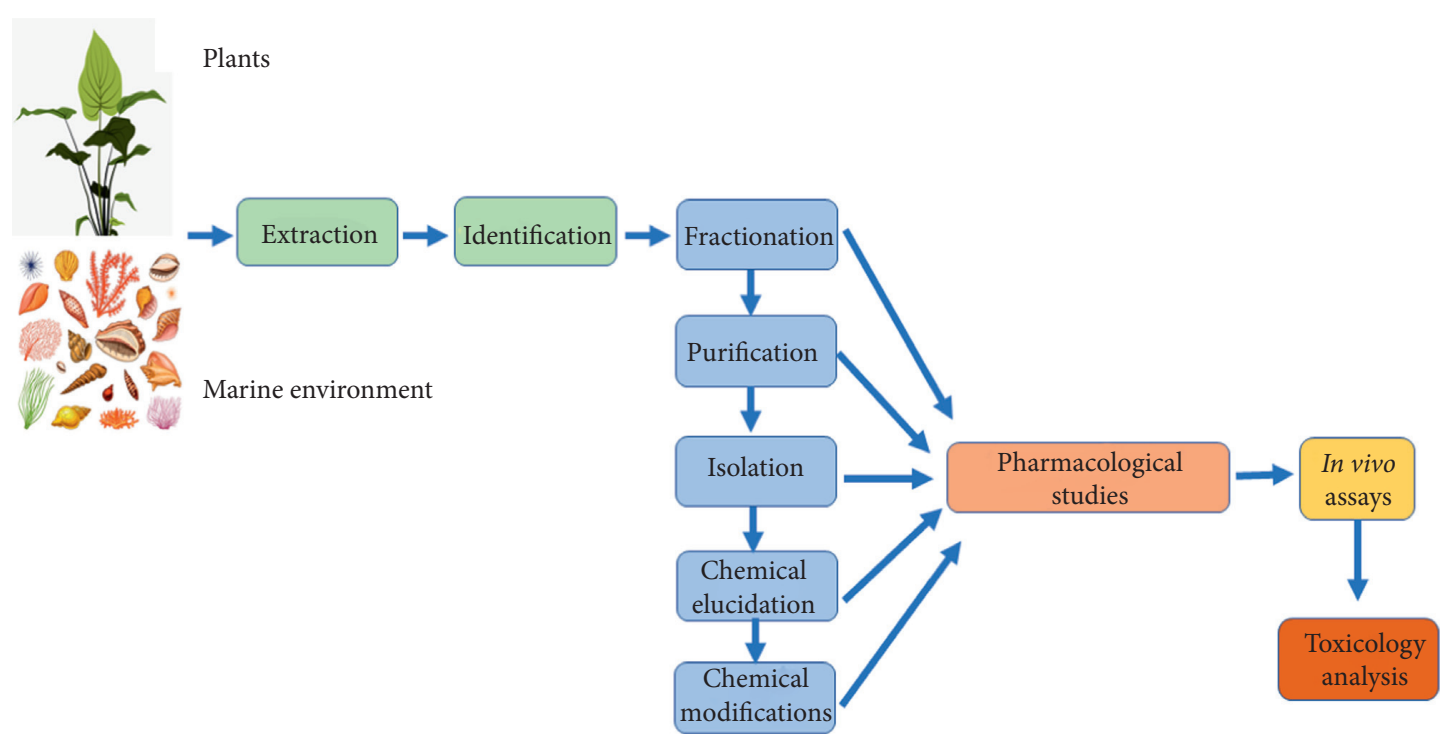

Figure 1: The model for the testing of alkaloids from plant and marine sources with antidepressant properties.

the motor and mental functions as well as by improving the sleep quality. Kavalactones have also been used as an alternative to the use of benzos in the treatment of depression [69].

5.5. Valeriana officinalis. Valerian is extensively used in various countries for its anticonvulsant, sedative, anxiolytic, and hypnotic-like effects [70]. Valepotriates and valerenic acid are active ingredients found in various pharmaceutical formulations. Furthermore, the crude extracts of valerian have been used in several countries [71]. Valepotriates containing triesters of otherwise unstable polyhydroxy cyclopenta-(c)-pyrans with carboxylic acids, namely, isovaleric, $\beta$-methylvaleric, valeric, $\beta$-hydroxyisovaleric, alpha(isovaleroxy)-isovaleric, beta-acetoxy-beta-methylvaleric, beta-acetoxy-isovaleric, and acetic acid, have been utilized as sedatives. The most thermolabile, unstable valerian components are valepotriates that decompose quickly in alkaline or acidic water, and also in alcoholic solvents [71]. Valepotriates have also been used for the improvement of human and animal pathological conditions during the withdrawal of benzodiazepine [72].

The mode of action is described as the interaction between valerian and GABA receptors inside the brain via GABA-aminotransferase inhibition, interference in intake and uptake of functional GABA within synaptosomes, and through the interaction of the benzodiazepine/GABA receptor [73].

\section{IAs of Marine Origin}

An increasing number of IAs have been reported from several marine organisms. Because of the occurrence of enzymes, i.e., haloperoxidases, within the marine ecosystem, the largest alkaloids group isolated from seaweeds, mollusks, ascidians, and sponges are halogenated.

Mono-IAs from the marine environment possess structural similarities to serotonin and have facilitated a better understanding of 5-HT receptor (5-HTR) function to synthesize novel drug compounds for treating migraines, anxiety, depression, and other disorders associated with 5HTR. Numerous compounds containing an indole ring possessing an affinity toward various serotonin receptors have been identified: 8,9 dihydrobarettin, sigma-conotoxin, barettin, and gelliusines $\mathrm{A}$ and $\mathrm{B}$ [74, 75]. Methylaplysinopsin obtained from the sponge Aplysinopsis reticulata has been found to inhibit the monoamine oxidases (Mao) and displace the serotonin from the receptor sites [76]. The other compounds of this group, N-3' ethylaplysinopsin, 6-bromoaplysinopsin, and 6-bromo $2^{\prime}$-de-Nmethylaplysinopsin, obtained from the sponge Smenospongia aurea have also been identified to displace the antagonist binding at $5 \mathrm{HT}_{2 \mathrm{~A}}$ and $5 \mathrm{HT}_{2 \mathrm{C}}$ receptors [77]. $\mathrm{N}-3^{\prime}$ ethylaplysinopsin has not shown selectivity toward any of these receptors. 6-Bromoaplysinopsin exhibited only a little selectivity to $5-\mathrm{HT}_{2 \mathrm{C}}$ receptors; conversely, 6-bromo $2^{\prime}$-de$\mathrm{N}$-methylaplysinopsin showed strong selectivity toward 5$\mathrm{HT}_{2 \mathrm{C}}$ receptors. In addition to neural activity, 6-bromoaplysinopsin has also exhibited significant activity against the malarial parasite Plasmodium falciparum.

Studies have shown the antimicrobial activity of 5bromo-DMT (5-bromo-N,N-dimethyltryptamine) and 5,6dibromo-DMT $[78,79]$. Both of these compounds have also been reported to have neurological activity: 5-bromo-DMT have shown powerful sedative activity in open field test; 5,6dibromo-DMT have exhibited antidepressant effect in tailsuspension and behavioral despair tests [80]. 5,6-DibromoDMT compound was considerably more effective than monobromotryptamine as it has also been reported to exhibit considerable antitumor activity in the MTT assay with HCT116 colorectal cancer cell lines [81]. An interesting and novel marine metabolite, possessing structural similarities to cannabinoids and indoles, has been found with powerful antidepressant action in behavioral despair tests [82].

A lot of naturally occurring IAs have not yet been evaluated for their neurological activity. However, their 
TABLE 1: The medicinal use of plants for the treatment of depression and/or anxiety.

\begin{tabular}{|c|c|c|c|c|c|}
\hline Plants & Active ingredients & Mechanism of action & $\begin{array}{l}\text { Therapeutic } \\
\text { purposes }\end{array}$ & $\begin{array}{c}\text { Study type } \\
\text { (animal mode/ } \\
\text { clinical) }\end{array}$ & References \\
\hline Actaea racemosa $\mathrm{L}$ & $\begin{array}{l}\text { Triterpenes and derivatives of } \\
\text { flavones }\end{array}$ & $\begin{array}{c}\text { Dopaminergic effect. Also, acts } \\
\text { on the hypothalamus } \\
\text { vasomotor center }\end{array}$ & $\begin{array}{l}\text { Anxiety and } \\
\text { depression }\end{array}$ & $\begin{array}{l}\text { Randomized } \\
\text { clinical trial }\end{array}$ & {$[26,27]$} \\
\hline $\begin{array}{l}\text { Agastache mexicana } \\
\text { subsp. Mexicana } \\
\text { (Lamiaceae) }\end{array}$ & Tilianin & $\begin{array}{c}\text { The ligand of } \mathrm{GABA}_{\mathrm{A}} / \mathrm{BZDs} \\
\text { receptor }\end{array}$ & $\begin{array}{l}\text { Nerve tonic and } \\
\text { tranquilizing }\end{array}$ & Mice & {$[28,29]$} \\
\hline $\begin{array}{l}\text { Agastache mexicana } \\
\text { subsp. Xolocotziana } \\
\text { (Lamiaceae) }\end{array}$ & Tilianin & GABAergic activity & $\begin{array}{l}\text { Nerve tonic and } \\
\text { tranquilizing }\end{array}$ & Mice & {$[28,30]$} \\
\hline $\begin{array}{l}\text { Annona cherimola } \\
\text { Mill. (Annonaceae) }\end{array}$ & $\begin{array}{c}\text { Liriodenine, nornuciferine, } \\
\text { and anonaine }\end{array}$ & $\begin{array}{c}\text { Increase in monoaminergic } \\
\text { neurotransmission }\end{array}$ & $\begin{array}{l}\text { Anxiety and } \\
\text { tranquilizing }\end{array}$ & Mice & {$[31]$} \\
\hline $\begin{array}{l}\text { Hypericum perforatum } \\
\text { L (Hypericaceae) }\end{array}$ & Hyperforin and hypericin & $\begin{array}{l}\text { A selective inhibitor of MAO-A } \\
\text { and MAO-B; inhibition of } \\
\text { serotonin, dopamine, and } \\
\text { norepinephrine uptake, the } \\
\text { antagonist of N-methyl-D- } \\
\text { aspartate receptor; interactions } \\
\text { with the GABA-A receptor }\end{array}$ & $\begin{array}{l}\text { Depression, } \\
\text { anxiety, and } \\
\text { insomnia }\end{array}$ & Clinical studies & {$[32,33]$} \\
\hline $\begin{array}{l}\text { Lavandula angustifolia } \\
\text { Mill. (Lamiacae) }\end{array}$ & Linalool and linalyl acetate & $\begin{array}{l}\text { Serotonin neurotransmission } \\
\text { through } 5-\mathrm{HT}_{1 \mathrm{~A}} \text { receptors }\end{array}$ & Depression & $\begin{array}{l}\quad \text { Mice } \\
\text { Randomized } \\
\text { clinical trial } \\
\end{array}$ & {$[34,35]$} \\
\hline $\begin{array}{l}\text { Litsea glaucescens } \\
\text { (Lauraceae) }\end{array}$ & Linalool and b-pinene & $\begin{array}{l}\text { Interaction with the } \\
\text { serotonergic } 5 \text { - } \mathrm{HT}_{1 \mathrm{~A}} \text { receptors, } \\
\alpha 2 \text {-adrenoceptor, and the } \beta 1 \text { - } \\
\text { adrenoceptors } \mathrm{D} 1 \text { receptor }\end{array}$ & Sadness & Mice & {$[36,37]$} \\
\hline $\begin{array}{l}\text { Melissa officinalis } \\
\text { L. (Lamiaceae) }\end{array}$ & $\begin{array}{c}\text { Rosmarinic acid and the } \\
\text { triterpenoids, ursolic acid, and } \\
\text { oleanolic acid }\end{array}$ & $\begin{array}{l}\text { Inhibitor of GABA } \\
\text { transaminase }\end{array}$ & $\begin{array}{c}\text { Benign } \\
\text { palpitations }\end{array}$ & $\begin{array}{l}\text { Randomized } \\
\text { clinical trial }\end{array}$ & {$[38]$} \\
\hline $\begin{array}{l}\text { Mimosa pudica } \\
\text { (Fabaceae) }\end{array}$ & $\begin{array}{c}\text { Norepinephrine, b-sitosterol, } \\
\text { d-pinitol, mimosine }\end{array}$ & $\begin{array}{l}\text { Mediated by the central } \\
\text { serotonergic system }\end{array}$ & $\begin{array}{c}\text { Depression and } \\
\text { insomnia }\end{array}$ & Rats & {$[39]$} \\
\hline Passiflora incarnata & $\begin{array}{l}\text { Orientin, isoorientin, vitexin, } \\
\text { isovitexin, and chrysin }\end{array}$ & $\begin{array}{c}\mathrm{GABA}_{\mathrm{A}} \text { and } \mathrm{GABA}_{\mathrm{B}} \text { receptors } \\
\text { agonist }\end{array}$ & $\begin{array}{c}\text { Generalized } \\
\text { anxiety disorder, } \\
\text { insomnia, and } \\
\text { depression }\end{array}$ & Clinical studies & {$[40,41]$} \\
\hline $\begin{array}{l}\text { Pimenta } \\
\text { pseudocaryophyllus } \\
\text { (Gomes) L.R. Landrum } \\
\end{array}$ & Dichloromethane fraction & $\begin{array}{l}\text { Effect on monoamine } \\
\text { biosynthesis }\end{array}$ & $\begin{array}{l}\text { Nerve tonic, a } \\
\text { calming agent }\end{array}$ & Mice & {$[42]$} \\
\hline $\begin{array}{l}\text { Piper methysticum } \\
\text { G. Foster }\end{array}$ & $\begin{array}{c}\text { Kavalactones, Kawain, } \\
\text { dihydrokavain }\end{array}$ & $\begin{array}{c}\text { Inhibition of MAO-B and } \\
\text { blocked the uptake of } \\
\text { noradrenaline }\end{array}$ & Anxiety & Clinical studies & {$[43,44]$} \\
\hline $\begin{array}{l}\text { Tagetes lucida Cav. } \\
\text { (Asteraceae) }\end{array}$ & $\begin{array}{l}\text { Quercetin, caffeic acid, gallic } \\
\text { acid }\end{array}$ & $\begin{array}{c}\text { Mediated by 5-HT1A and 5- } \\
\text { HT2A receptors }\end{array}$ & $\begin{array}{c}\text { Anxiety and } \\
\text { depression }\end{array}$ & Rats & {$[45,46]$} \\
\hline Valeriana officinalis L. & Valerenic acid and valerenol & $\begin{array}{c}\text { Enhance the response to } \\
\text { GABA }_{\mathrm{A}} \text { receptors }\end{array}$ & $\begin{array}{c}\text { Sleep and anxiety } \\
\text { disorders }\end{array}$ & $\begin{array}{l}\text { Mice, clinical } \\
\text { studies }\end{array}$ & {$[47,48]$} \\
\hline
\end{tabular}

structures reveal a possible affinity toward dopamine, adrenergic, and serotonin receptors. A fraction comprising 6bromotryptamine has been reported to exhibit in-vitro antifungal and antimicrobial activity [83]. One more tryptamine derivative, $\mathrm{Nb}$-acetyltryptamine, has been obtained from an unclassified marine fungus that grows on the Gracilaria verrucose surface [84]. This compound along with the deacetylated derivative has been identified from a marine bacterial specie Roseivirga echinicomitans $\left(\mathrm{KMM} 6058^{\mathrm{T}}\right.$ ), which is associated with Strongylocentrotus intermedius (sea urchin) [85]. These compounds were observed to be slightly cytotoxic to Erlich carcinoma cells; N,N-diacetyltryptamine showed greater hemolytic activity causing $50 \%$ damage to egg and sperm cells membrane at 15 and $7.5 \mu \mathrm{g} /$ $\mathrm{ml}$ concentrations, respectively. The dibrominated compounds 12 and 11 were initially reported as antimicrobial metabolites isolated from a Polyfibrospongia maynardii sponge [86]. Later on, these alkaloids were obtained from the 
marine sponge Hyrtios erecta and observed to be involved in selective inhibition of nitric oxide synthases (neuronal isoform) [87].

Three bromoindoles obtained from the mid-intestinal gland of the gastropod mollusk Drupella fragum have been found to exhibit antioxidative properties [88]. 6-BroMo-5hydroxyindole showed greater antioxidant activity than the alpha-tocopherol. Two more compounds, 6-bromoindole-3carboxaldehyde along with its debromo analog, were extracted from a species of Acinetobacter, a bacteria obtained from the surface of S. murrayi [89]. This brominated alkaloid exhibited antibacterial activity as well as inhibited the larval settlement of the Barnacle, Balanus Amphitrite.

A novel indole derivative named 3-indoleacrylamide has been reported to have an in-vitro antihelminthic activity [90]. The heterocyclic compound was obtained from the Chondria atropurpurea (red alga) along with many other known indole and bisindole alkaloids. One more antimicrobial indole was obtained from the Palauan ascidian Distaplia regina [91]. Moreover, monoindole alkaloids were found regulating the plant growth mechanism: this kind of activity has also been reported for indole-3-acetamide as well as 3-(hydroxyacetyl)indole [92].

\section{Synthetic IAs}

In the literature, numerous studies have been focused toward synthesizing selective 5-HT receptor ligands. Several structures have been identified as selective and potent agents for 5-HTRs; some of them have structural similarities to compounds obtained from sponges. 2-Ethyl-5-methoxy$N, N$-dimethyltryptamine (EMDT), a tryptamine derivative, was synthesized as a first selective agonist for the $5-\mathrm{HT}_{6}$ receptor [93].

Several structure-activity relationship (SAR) studies have reported the promising structures for both antagonists and agonists of 5-HTRs. Quantitative SAR (QSAR) and structure affinity relationship of numerous tryptamine derivatives have been investigated for a $5-\mathrm{HT}_{1 \mathrm{E}}$-like receptor subtype [94]. Findings revealed that the chain of two atoms involved in the separation of the indole ring from its amine functional group is important for the interaction of tryptamine analogs with receptors. Moreover, the branching of the chain results in decreased affinity. Therefore, the indole ring seems crucial for receptor affinity and changes in the benzene ring or substitution of the $\mathrm{NH}$ group with $\mathrm{S}$ will decrease the receptor affinity. However, the replacement of the amine functional group, only if the substituent groups remain smaller, will not affect the affinity.

Agents that bind to the $5-\mathrm{HT}_{6}$ receptors have also been extensively studied [95]. In a study, it was identified that $\mathrm{N}, \mathrm{N}$-dimethylation, or $\mathrm{N}$-monomethylation, of 5 -HT derivatives can result in a small increase in the binding affinity. In 5-HT derivatives, the primary $\left(1^{\circ}\right)$ amine can metabolize rapidly through oxidative deamination causing problems by decreasing the capability of a compound for crossing the $\mathrm{BBB}$ (blood-brain barrier). The substitution of a primary $\left(1^{\circ}\right)$ amine with secondary $\left(2^{\circ}\right)$ or tertiary $\left(3^{\circ}\right)$ amines can increase the molecular lipophilicity, making it less susceptible to metabolism, as well as increasing its probability of being used as an effective drug.

In a study, it was reported that oxindoles have an antidepressant-like effect, and SAR studies revealed that the best possible sidechain for these heterocyclic compounds could be $(\mathrm{CH} 2) 3 \mathrm{NHCH} 3$ or any group capable of metabolizing to this. The branching of the sidechain can result in a reduced effect similar to the replacement of the indolinone ring. The replacement at the nitrogen atom of a heterocycle must be a phenyl group, and the substitution of the group at 3 -position on indolinone must be small for maintaining the activity [96]. It was reported that 2-substituted tryptamines possess pharmacological activity. Among the compounds tested in this study, 2(2-methyl-2-amino)-propylindole hydrochloride was involved in motor excitation, tail and limbs tremor, stereotyped head spasm in rats and mice [97].

The latest medicinal and synthetic chemistry-based research has concentrated on the synthesis of various types of specific ligands for 5-HTRs. In a study, 5-alkhyltryptamine analogs were evaluated for finding the substituents that are important for the binding affinity of the particular molecule toward $5-\mathrm{HT}_{1 \mathrm{D}}$ receptors [98]. It was also revealed that the substituent at 5-position did not require properties of H-bonding for exhibiting a strong binding affinity to this receptor, as the size of a group determines the affinity. $\mathrm{N}$ Methyl-5-tert-butyltryptamine exhibited a greater affinity toward $5-\mathrm{HT}_{1 \mathrm{D}}$ receptor, and compound 56 was the most powerful agonist with a $\mathrm{Ki}$ value of $0.45 \mathrm{nM}$.

A research group investigated thieno [3,2-b]- and thieno [2,3-b]-pyrrole bioisosteric analogs of DMT and found that the thiophene compound cannot be used as a substituent of the phenyl group within the indole ring of tryptamine compounds that bind to the $5-\mathrm{HT}_{2}$ receptors [99]. Nevertheless, the thiophene compounds could be an appropriate bioisosteric replacement for compounds showing an activity toward the 5- $\mathrm{HT}_{1 \mathrm{~A}}$ receptor. In another study, this research group investigated how fluorination affects the hallucinogen-like activity of tryptamines [100]. Their findings exhibited that fluorination of the tryptamine compounds at position, 5,4,7, and 6 reduces their hallucinogen-like activity. The introduction of fluorine at position 6 of the 5-methoxyDMT (5-MeO-DMT) reduces the binding affinity toward the $5-\mathrm{HT}_{1 \mathrm{~A}}$ receptor. However, in the case of the DMT, the fluorination at 6-position led to a five-time decrease in binding affinity to the $5-\mathrm{HT}_{1 \mathrm{~A}}$ receptor.

Ring fluorination of 5-MeO-DMT at 4-position resulted in an increased affinity for the $5 \mathrm{HT}_{1 \mathrm{~A}}$ receptor, which yielded a selective and potent 4-fluoro-5-MeO-DMT (Ki $0.23 \mathrm{nM}$ ). The fluorination of $5-\mathrm{HT}_{2 \mathrm{C}}$ and $5-\mathrm{HT}_{2 \mathrm{~A}}$ receptors at the 6 th position insignificantly affected the affinity toward these receptors. A study reported the process for the synthesis of $\mathrm{N}$-(2-arylethyl)-benzamine compounds as potent $5-\mathrm{HT}_{6}$ antagonists. The researchers revealed that these antagonists can be used for the treatment of neurocognitive disorders and several other disorders that are related to $5-\mathrm{HT}_{6}$ receptors, such as schizophrenia, anxiety, migraine, epilepsy, sleep disorders, Parkinson's disease, convulsions, and cognitive disorders associated with the age. 
The studies have found that several tryptamine-like intermediate compounds and 8-substituted-tetrahydro$\beta$-carbolines possess a great affinity for all the $5-\mathrm{HT}_{2}$ receptor subtypes [101]. In another report, the compounds were synthesized with a high affinity toward $5-\mathrm{HT}_{2 \mathrm{~B}}$, 5$\mathrm{HT}_{2 \mathrm{C}}$, and $5-\mathrm{HT}_{2 \mathrm{~A}}$ receptors, which can be used for the management of several disorders related to these receptors, like dyspepsia, depression, tachygastria, schizophrenia, migraines, anxiety, and achalasia. The indole derivatives along with their affinity toward $5-\mathrm{HT}_{2}$ were reported to be effective for the treatment of mammals that suffer from 5HT2-associated disorders, e.g., depression, anxiety, and hypertension. Moreover, few more indole compounds were revealed as potential inhibitors of the angiogenesis pathway, which has an important role in the development of cancer, inflammatory and immune disorders.

A novel subtype of 5-HTRs, i.e., the $5-\mathrm{HT}_{7}$ was recently found to be associated with psychiatric disorders, for example, schizophrenia and depression; however, their function is still not widely known. In a comprehensive investigation, the inverse agonists for these receptors were described, and it was revealed that derivatives of tryptamine, e.g., compound 111 with no added aromatic rings display only reduced affinity to these receptors [102].

Several enantiomers of alpha-methyltryptamines (AMTs) were investigated. The researchers examined the analogs of tryptamine in 5-HT2 and 5-HT1B receptorbinding assays, which revealed that both the binding sites have different enantioselectivity, depending on their aromatic substituents. In both the subtypes, the binding affinity for AMTs was in the order: 5-substituted $>4$ substituted $>$ unsubstituted $>6$-substituted. For $\alpha$-methtylserotonin, the $S$-isomer exhibited greater affinity toward both receptors than the $R$-isomer. In the case of compounds 118 and 115 , the R-isomers displayed greater affinity to 5$\mathrm{HT}_{1 \mathrm{~B}}$ but not toward 5- $\mathrm{HT}_{2}$ [103].

Three novel IAs were synthesized through microbial biotransformation using $S$. staurosporeus. The bacterium was fed with the 6-fluoro-tryptamine, 5-fluror-tryptamine hydrochloride, and tryptamine hydrochloride, obtained from the bacterial cultures and extracted with beta-hydroxy-Nbacetyltrptamine along with its 6- and 5-fluoro derivatives [104]. Procedures for the synthesis and the insecticidal activities of numerous simple IAs have been explained in a study. Salts, stereoisomers, and drugs having the aryl-thioether tryptamine derivatives have been reported to be useful for central nervous system diseases that are associated with the $5-\mathrm{HT}_{6}$ receptors, e.g., depression, anxiety, and movement disorders.

\section{New Indole and Tryptamine Derivatives}

One novel compound studied in the past several years that possesses structural similarities to the IAs belongs to the Wyeth compounds, i.e., WAY 161503 , which is a selective agonist of the 5-HT2C receptor, and which is involved in various aspects related to mood, appetite control, and reward-related behavior [105]. WAY 161503 is protected by multiple patents and is reported to be effective for the prevention and management of involuntary urination and clinical depression.

One more compound, WAY 163909, a potent and selective agonist of the $5-\mathrm{HT}_{2 \mathrm{C}}$ receptor, has also been found to be useful for the treatment of obesity. This compound displayed antipsychotic and antidepressant activity in animal models. PD-6735 (TIK-301), a melatonin agonist that has just finished Phase II trials for blind individuals associated with sleep disorders, also contains a structural indole moiety. This drug not only proved to be effective in the reestablishment of the right day-night cycle but also exhibited a good safety profile.

\section{Conclusion}

The major limitations of the studies are the use of crude or semi-purified phytochemicals for the treatment of psychiatric diseases. Moreover, the results of the studies in animal models and/or clinical trials vary and lack reproducibility. This may be due to disparities in the metabolite contents in different geographical areas owing to the climate, the ecological conditions, and the availability of nutrients. Additionally, the bioactivity of phytochemicals may be attributed to the mixture of compounds; therefore, it is suggested to obtain the active ingredients followed by identification and metabolomics study for the better characterization of these phytochemicals.. Moreover, the chemical synthesis of indole alkaloids is also proposed as indole alkaloids from natural sources are quite complex. The synthetic IAs can be a better option as the structure of various receptors and enzyme inhibitors are available. However, some of the naturally occurring IAs may not be synthesized by the available methods. The marine IAs also have an incredible potential for the treatment of the different psychiatric disorders; therefore, further studies can offer better insights to the utility of the IAs for the amelioration of anxiety and depressive disorders. In conclusion, several IAs, especially from the plants, have been used as antianxiety medication and antidepressants. In the future, this reservoir of IAs from plants can be utilized as a valuable starting point to develop effective alternatives for the therapeutic management of depression and anxiety-related disorders.

Initially, the standard crude extracts are prepared, followed by the phytochemical studies including fractionation, purification, isolation, and chemical elucidation of phytoconstituents. These alkaloids can either be modified structurally or new compounds are synthesized based on the chemical structure of the alkaloids. The pharmacological studies of the crude extracts as well as the fractioned, isolated, and chemically modified compounds are performed for antianxiety and/or antidepressant properties. In vitro assays including the light-dark box test, open field, elevated plus-maze, tail suspension test, and forced swimming test are performed. Finally, the toxicological tests are performed in cell culture using animal models. 


\section{Conflicts of Interest}

The authors declare that they have no conflicts of interest.

\section{References}

[1] GBD 2017 Disease and Injury Incidence and Prevalence Collaborators, "Global, regional, and national incidence, prevalence, and years lived with disability for 354 diseases and injuries for 195 countries and territories, 1990-2017: a systematic analysis for the Global Burden of Disease Study 2017," Lancet, vol. 392, no. 10159, pp. 1789-1858, 2018.

[2] T. McCarter, "Depression overview," American Health \& Drug Benefits, vol. 1, no. 3, pp. 44-51, 2008.

[3] J. Yim, "Therapeutic benefits of laughter in mental health: a theoretical review," The Tohoku Journal of Experimental Medicine, vol. 239, no. 3, pp. 243-249, 2016.

[4] A. McCarthy, K. Wafford, E. Shanks, M. Ligocki, D. M. Edgar, and D.-J. Dijk, "REM sleep homeostasis in the absence of REM sleep: effects of antidepressants," Neuropharmacology, vol. 108, pp. 415-425, 2016.

[5] G. Gartlehner, G. Wagner, N. Matyas et al., "Pharmacological and non-pharmacological treatments for major depressive disorder: review of systematic reviews," BMJ Open, vol. 7, no. 6, p. e014912, 2017.

[6] L.-P. Guan and B.-Y. Liu, "Antidepressant-like effects and mechanisms of flavonoids and related analogues," European Journal of Medicinal Chemistry, vol. 121, pp. 47-57, 2016.

[7] J. O. Fajemiroye, D. M. da Silva, D. R. de Oliveira, and E. A. Costa, "Treatment of anxiety and depression: medicinal plants in retrospect," Fundamental \& Clinical Pharmacology, vol. 30, no. 3, pp. 198-215, 2016.

[8] F. de Sá Alves, E. Barreiro, and C. Manssour Fraga, "From nature to drug discovery: the indole scaffold as a 'privileged structure," Mini-Reviews in Medicinal Chemistry, vol. 9, no. 7, pp. 782-793, 2009.

[9] H. A. Hamid, A. N. Ramli, and M. M. Yusoff, "Indole alkaloids from plants as potential leads for antidepressant drugs: a mini review," Frontiers in Pharmacology, vol. 8, p. 96, 2017.

[10] S. Sagi, B. Avula, Y.-H. Wang, and I. A. Khan, "Quantification and characterization of alkaloids from roots of Rauwolfia serpentina using ultra-high performance liquid chromatography-photo diode array-mass spectrometry," Analytical and Bioanalytical Chemistry, vol. 408, no. 1, pp. 177-190, 2016.

[11] J. Zhu, M. Wang, W. Wen, and R. Yu, "Biosynthesis and regulation of terpenoid indole alkaloids in Catharanthus roseus," Pharmacognosy Reviews, vol. 9, no. 17, pp. 24-28, 2015.

[12] Y. Shimazaki, T. Yajima, M. Takani, and O. Yamauchi, "Metal complexes involving indole rings: structures and effects of metal-indole interactions," Coordination Chemistry Reviews, vol. 253, no. 3-4, pp. 479-492, 2009.

[13] F. D. Sheftell, M. E. Bigal, S. J. Tepper, and A. M. Rapoport, "Sumatriptan: a decade of use and experience in the treatment of migraine," Expert Review of Neurotherapeutics, vol. 4, no. 2, pp. 199-209, 2004.

[14] S. D. Silberstein, "A review of clinical safety data for sumatriptan nasal powder administered by a breath powered exhalation delivery system in the acute treatment of migraine," Expert Opinion on Drug Safety, vol. 17, no. 1, pp. 89-97, 2018.
[15] F. Markus and K. Mikko, "Frovatriptan review," Expert Opinion on Pharmacotherapy, vol. 8, no. 17, pp. 3029-3033, 2007.

[16] E. A. Balbisi, "Frovatriptan succinate, a 5-HT1B/1D receptor agonist for migraine," International Journal of Clinical Practice, vol. 58, no. 7, pp. 695-705, 2004.

[17] E. Rubio-Beltrán, A. Labastida-Ramírez, C. M. Villalón, and A. MaassenVanDenBrink, "Is selective 5-HT 1F receptor agonism an entity apart from that of the triptans in antimigraine therapy?" Pharmacology \& Therapeutics, vol. 186, pp. 88-97, 2018.

[18] M. Ferrari, P. Goadsby, K. Roon, and R. Lipton, "Triptans (serotonin, 5-HT1B/1D agonists) in migraine: detailed results and methods of a meta-analysis of 53 trials," Cephalalgia, vol. 22, no. 8, pp. 633-658, 2002.

[19] F. Antonaci, N. Ghiotto, S. Wu, E. Pucci, and A. Costa, "Recent advances in migraine therapy," Springerplus, vol. 5, p. 637, 2016.

[20] D. E. Nichols, "Structure-activity relationships of serotonin 5-HT2Aagonists," Wiley Interdisciplinary Reviews: Membrane Transport and Signaling, vol. 1, no. 5, pp. 559-579, 2012.

[21] S. Köhler, K. Cierpinsky, G. Kronenberg, and M. Adli, "The serotonergic system in the neurobiology of depression: relevance for novel antidepressants," Journal of Psychopharmacology, vol. 30, no. 1, pp. 13-22, 2016.

[22] T. M. Hillhouse and J. H. Porter, "A brief history of the development of antidepressant drugs: from monoamines to glutamate," Experimental and Clinical Psychopharmacology, vol. 23, no. 1, pp. 1-21, 2015.

[23] T. A. Jenkins, J. C. Nguyen, K. E. Polglaze, and P. P. Bertrand, "Influence of tryptophan and serotonin on mood and cognition with a possible role of the gut-brain axis," Nutrients, vol. 8, no. 1, 2016.

[24] W. E. Fantegrossi, K. S. Murnane, and C. J. Reissig, "The behavioral pharmacology of hallucinogens," Biochemical Pharmacology, vol. 75, no. 1, pp. 17-33, 2008.

[25] D. Hoyer, "5-HT receptor nomenclature: naming names, does it matter? A tribute to Maurice rapport," ACS Chemical Neuroscience, vol. 8, no. 5, pp. 908-919, 2017.

[26] D. J. McKenna, K. Jones, S. Humphrey, and K. Hughes, "Black cohosh: efficacy, safety, and use in clinical and preclinical applications," Alternative Therapies in Health and Medicine, vol. 7, no. 3, pp. 93-100, 2001.

[27] S. Mohammad-Alizadeh-Charandabi, M. Shahnazi, J. Nahaee, and S. Bayatipayan, "Efficacy of black cohosh (Cimicifuga racemosa L.) in treating early symptoms of menopause: a randomized clinical trial," Chinese Medicine, vol. 8, no. 1, p. 20, 2013.

[28] R. Estrada-Reyes, C. López-Rubalcava, O. A. Ferreyra-Cruz et al., "Central nervous system effects and chemical composition of two subspecies of Agastache mexicana; an ethnomedicine of Mexico," Journal of Ethnopharmacology, vol. 153, no. 1, pp. 98-110, 2014.

[29] M. E. González-Trujano, H. Ponce-Muñoz, S. HidalgoFigueroa, G. Navarrete-Vázquez, and S. Estrada-Soto, "Depressant effects of Agastache mexicana methanol extract and one of major metabolites tilianin," Asian Pacific Journal of Tropical Medicine, vol. 8, no. 3, pp. 185-190, 2015.

[30] J. Gálvez, R. Estrada-Reyes, G. Benítez-King et al., "Involvement of the GABAergic system in the neuroprotective and sedative effects of acacetin 7-O-glucoside in rodents," Restorative Neurology and Neuroscience, vol. 33, no. 5, pp. 683-700, 2015. 
[31] M. Martínez-Vázquez, R. Estrada-Reyes, A. G. Araujo Escalona et al., "Antidepressant-like effects of an alkaloid extract of the aerial parts of Annona cherimolia in mice," Journal of Ethnopharmacology, vol. 139, no. 1, pp. 164-170, 2012.

[32] E. Russo, F. Scicchitano, B. J. Whalley et al., "Hypericum perforatum: Pharmacokinetic, mechanism of action, tolerability, and clinical drug-drug interactions," Phytotherapy Research, vol. 28, no. 5, pp. 643-655, 2014.

[33] A. R. Bilia, S. Gallori, and F. F. Vincieri, "St. John's wort and depression," Life Sciences, vol. 70, no. 26, pp. 3077-3096, 2002.

[34] S. Akhondzadeh, L. Kashani, A. Fotouhi et al., "Comparison of Lavandula angustifolia Mill. tincture and imipramine in the treatment of mild to moderate depression: a doubleblind, randomized trial," Progress in Neuro-Psychopharmacology and Biological Psychiatry, vol. 27, no. 1, pp. 123-127, 2003.

[35] L. R. Chioca, M. M. Ferro, I. P. Baretta et al., "Anxiolytic-like effect of lavender essential oil inhalation in mice: participation of serotonergic but not GABAA/benzodiazepine neurotransmission," Journal of Ethnopharmacology, vol. 147, no. 2, pp. 412-418, 2013.

[36] S. L. Guzmán-Gutiérrez, H. Bonilla-Jaime, R. Gómez-Cansino, and R. Reyes-Chilpa, "Linalool and $\beta$-pinene exert their antidepressant-like activity through the monoaminergic pathway," Life Sciences, vol. 128, pp. 24-29, 2015.

[37] S. L. Guzmán-Gutiérrez, R. Gómez-Cansino, J. C. GarcíaZebadúa, N. C. Jiménez-Pérez, and R. Reyes-Chilpa, “Antidepressant activity of Litsea glaucescens essential oil: identification of $\beta$-pinene and linalool as active principles," Journal of Ethnopharmacology, vol. 143, no. 2, pp. 673-679, 2012.

[38] F. Alijaniha, M. Naseri, S. Afsharypuor et al., "Heart palpitation relief with Melissa officinalis leaf extract: double blind, randomized, placebo controlled trial of efficacy and safety," Journal of Ethnopharmacology, vol. 164, pp. 378-384, 2015.

[39] S. L. G. Gutiérrez, R. R. Chilpa, and H. B. Jaime, "Medicinal plants for the treatment of "nervios," anxiety, and depression in Mexican Traditional Medicine," Revista Brasileira de Farmacognosia, vol. 24, no. 5, pp. 591-608, 2014.

[40] F. Fahami, Z. Asali, A. Aslani, and N. Fathizadeh, "A comparative study on the effects of Hypericum Perforatum and passion flower on the menopausal symptoms of women referring to Isfahan city health care centers," Iranian Journal of Nursing and Midwifery Research, vol. 15, no. 4, pp. 202207, 2010.

[41] M. Miroddi, G. Calapai, M. Navarra, P. L. Minciullo, and S. Gangemi, "Passiflora incarnata L.: ethnopharmacology, clinical application, safety and evaluation of clinical trials," Journal of Ethnopharmacology, vol. 150, no. 3, pp. 791-804, 2013.

[42] J. O. Fajemiroye, J. L. Martins, P. C. Ghedini et al., "Antidepressive-like property of dichloromethane fraction of Pimenta pseudocaryophyllus and relevance of monoamine metabolic enzymes," Evidence-Based Complementary and Alternative Medicine, vol. 2013, Article ID 659391, 2013.

[43] E. Lehmann, E. Kinzler, and J. Friedemann, "Efficacy of a special Kava extract (Piper methysticum) in patients with states of anxiety, tension and excitedness of non-mental origin-A double-blind placebo-controlled study of four weeks treatment," Phytomedicine, vol. 3, no. 2, pp. 113-119, 1996.
[44] J. Sarris, C. Stough, C. A. Bousman et al., "Kava in the treatment of generalized anxiety disorder," Journal of Clinical Psychopharmacology, vol. 33, no. 5, pp. 643-648, 2013.

[45] H. Bonilla-Jaime, G. Guadarrama-Cruz, F. J. AlarconAguilar, O. Limón-Morales, and G. Vazquez-Palacios, "Antidepressant-like activity of Tagetes lucida Cav. is mediated by 5-HT1A and 5-HT2A receptors," Journal of Natural Medicines, vol. 69, no. 4, pp. 463-470, 2015.

[46] G.-C. Gabriela, A.-A. F. Javier, V.-A. Elisa, V.-P. Gonzalo, and B.-J. Herlinda, "Antidepressant-like effect of Tagetes lucida Cav. extract in rats: involvement of the serotonergic system," The American Journal of Chinese Medicine, vol. 40, no. 4, pp. 753-768, 2012.

[47] R. Andreatini, V. n. A. Sartori, M. L. V. Seabra, and J. R. Leite, "Effect of valepotriates (valerian extract) in generalized anxiety disorder: a randomized placebo-controlled pilot study," Phytotherapy Research, vol. 16, no. 7, pp. 650-654, 2002.

[48] D. Benke, A. Barberis, S. Kopp et al., "GABAA receptors as in vivo substrate for the anxiolytic action of valerenic acid, a major constituent of valerian root extracts," Neuropharmacology, vol. 56, no. 1, pp. 174-181, 2009.

[49] E. A. Carlini, "Plants and the central nervous system," Pharmacology Biochemistry and Behavior, vol. 75, no. 3, pp. 501-512, 2003.

[50] K. Jawna-Zboińska, K. Blecharz-Klin, I. Joniec-Maciejak et al., "Passiflora incarnata L. improves spatial memory, reduces stress, and affects neurotransmission in rats," Phytotherapy Research, vol. 30, no. 5, pp. 781-789, 2016.

[51] B. Vicknasingam, S. Narayanan, G. T. Beng, and S. M. Mansor, "The informal use of ketum (Mitragyna speciosa) for opioid withdrawal in the northern states of peninsular Malaysia and implications for drug substitution therapy," International Journal of Drug Policy, vol. 21, no. 4, pp. 283-288, 2010.

[52] F. León, E. Habib, J. E. Adkins, E. B. Furr, C. R. McCurdy, and S. J. Cutler, "Phytochemical characterization of the leaves of Mitragyna speciosa grown in USA," Natural Product Communications, vol. 4, no. 7, pp. 907-910, 2009.

[53] E. Kumarnsit, U. Vongvatcharanon, N. Keawpradub, and P. Intasaro, "Fos-like immunoreactivity in rat dorsal raphe nuclei induced by alkaloid extract of Mitragyna speciosa," Neuroscience Letters, vol. 416, no. 2, pp. 128-132, 2007.

[54] N. F. Idayu, M. T. Hidayat, M. A. Moklas et al., "Antidepressant-like effect of mitragynine isolated from Mitragyna speciosa Korth in mice model of depression," Phytomedicine: International Journal of Phytotherapy and Phytopharmacology, vol. 18, no. 5, pp. 402-407, 2011.

[55] M. L. Leporatti and K. Ghedira, "Comparative analysis of medicinal plants used in traditional medicine in Italy and Tunisia," Journal of Ethnobiology and Ethnomedicine, vol. 5, p. 31, 2009.

[56] T. Herraiz, D. González, C. Ancín-Azpilicueta, V. J. Arán, and H. Guillén, " $\beta$-carboline alkaloids in Peganum harmala and inhibition of human monoamine oxidase (MAO)," Food and Chemical Toxicology, vol. 48, no. 3, pp. 839-845, 2010.

[57] B. E. Abu-Irmaileh and F. U. Afifi, "Herbal medicine in Jordan with special emphasis on commonly used herbs," Journal of Ethnopharmacology, vol. 89, no. 2-3, pp. 193-197, 2003.

[58] L. Farouk, A. Laroubi, R. Aboufatima, A. Benharref, and A. Chait, "Evaluation of the analgesic effect of alkaloid extract of Peganum harmala L.: possible mechanisms 
involved," Journal of Ethnopharmacology, vol. 115, no. 3, pp. 449-454, 2008.

[59] H. R. Monsef, A. Ghobadi, M. Iranshahi, and M. Abdollahi, "Antinociceptive effects of Peganum harmala L. alkaloid extract on mouse formalin test," Journal of Pharmacy and Pharmaceutical Sciences, vol. 7, no. 1, pp. 65-69, 2004.

[60] J. J. Fortunato, G. Z. Réus, T. R. Kirsch et al., "Acute harmine administration induces antidepressive-like effects and increases BDNF levels in the rat hippocampus," Progress in Neuro-Psychopharmacology and Biological Psychiatry, vol. 33, no. 8, pp. 1425-1430, 2009.

[61] D. Farzin and N. Mansouri, "Antidepressant-like effect of harmane and other $\beta$-carbolines in the mouse forced swim test," European Neuropsychopharmacology, vol. 16, no. 5, pp. 324-328, 2006.

[62] M. Nasehi, M. Piri, M. Nouri, D. Farzin, T. Nayer-Nouri, and M. R. Zarrindast, "Involvement of dopamine D1/D2 receptors on harmane-induced amnesia in the step-down passive avoidance test," European Journal of Pharmacology, vol. 634, no. 1-3, pp. 77-83, 2010.

[63] M. Moloudizargari, P. Mikaili, S. Aghajanshakeri, M. Asghari, and J. Shayegh, "Pharmacological and therapeutic effects of Peganum harmala and its main alkaloids," Pharmacognosy Reviews, vol. 7, no. 14, pp. 199-212, 2013.

[64] A.-M. Yu, J. R. Idle, K. W. Krausz, A. Küpfer, and F. J. Gonzalez, "Contribution of Individual Cytochrome $\mathrm{P} 450$ isozymes to the O-demethylation of the psychotropic $\beta$-carboline alkaloids harmaline and harmine," Journal of Pharmacology and Experimental Therapeutics, vol. 305, no. 1, pp. 315-322, 2003.

[65] F. Splettstoesser, U. Bonnet, M. Wiemann, D. Bingmann, and D. Büsselberg, "Modulation of voltage-gated channel currents by harmaline and harmane," British Journal of Pharmacology, vol. 144, no. 1, pp. 52-58, 2005.

[66] T. Herraiz and H. Guillén, "Inhibition of the bioactivation of the neurotoxin MPTP by antioxidants, redox agents and monoamine oxidase inhibitors," Food and Chemical Toxicology, vol. 49, no. 8, pp. 1773-1781, 2011.

[67] A. R. Bilia, S. Gallori, and F. F. Vincieri, "Kava-kava and anxiety: growing knowledge about the efficacy and safety," Life Sciences, vol. 70, no. 22, pp. 2581-2597, 2002.

[68] H. Grunze, J. Langosch, K. Schirrmacher, D. Bingmann, J. Von Wegerer, and J. Walden, "Kava pyrones exert effects on neuronal transmission and transmembraneous cation currents similar to established mood stabilizers-a review," Progress in Neuro-Psychopharmacology and Biological Psychiatry, vol. 25, no. 8, pp. 1555-1570, 2001.

[69] U. Malsch and M. Kieser, "Efficacy of kava-kava in the treatment of non-psychotic anxiety, following pretreatment with benzodiazepines," Psychopharmacology, vol. 157, no. 3, pp. 277-283, 2001.

[70] N. Ghaderi and M. Jafari, "Efficient plant regeneration, genetic fidelity and high-level accumulation of two pharmaceutical compounds in regenerated plants of Valeriana officinalis L." South African Journal of Botany, vol. 92, pp. 19-27, 2014.

[71] R. Bos, H. J. Woerdenbag, and N. Pras, "Determination of valepotriates," Journal of Chromatography A, vol. 967, no. 1, pp. 131-146, 2002.

[72] D. R. Poyares, C. Guilleminault, M. M. Ohayon, and S. Tufik, "Can valerian improve the sleep of insomniacs after benzodiazepine withdrawal?" Progress in Neuro-Psychopharmacology and Biological Psychiatry, vol. 26, no. 3, pp. 539-545, 2002.
[73] K. Sichardt, Z. Vissiennon, U. Koetter, A. Brattström, and K. Nieber, "Modulation of postsynaptic potentials in rat cortical neurons by valerian extracts macerated with different alcohols: involvement of adenosine A1- and GABAAreceptors," Phytotherapy Research, vol. 21, no. 10, pp. 932-937, 2007.

[74] E. Hedner, M. Sjögren, P.-A. Frändberg et al., "Brominated cyclodipeptides from the marine spongegeodiabarrettias selective 5-HT ligands," Journal of Natural Products, vol. 69, no. 10, pp. 1421-1424, 2006.

[75] L. J. England, J. Imperial, R. Jacobsen et al., "Inactivation of a serotonin-gated ion channel by a polypeptide toxin from marine snails," Science, vol. 281, no. 5376, pp. 575-578, 1998.

[76] J. Baird-Lambert, P. A. Davis, and K. M. Taylor, "Methylaplysinopsin: a natural product of marine origin with effects on serotonergic neurotransmission," Clinical and Experimental Pharmacology and Physiology, vol. 9, no. 2, pp. 203-212, 1982.

[77] J.-F. Hu, J. A. Schetz, M. Kelly et al., "New antiinfective and human 5-HT2 receptor binding natural and semisynthetic compounds from the jamaican spongesmenospongiaaurea," Journal of Natural Products, vol. 65, no. 4, pp. 476-480, 2002.

[78] C. Debitus, D. Laurent, and M. Païs, "Alcaloïdes d'une ascidie neocaledonienne, eudistoma fragum," Journal of Natural Products, vol. 51, no. 4, pp. 799-801, 1988.

[79] A. A. Tymiak, K. L. Rinehart Jr., and G. J. Bakus, "Constituents of morphologically similar sponges," Tetrahedron, vol. 41, no. 6, pp. 1039-1047, 1985.

[80] J. A. Diers, K. D. Ivey, A. El-Alfy et al., "Identification of antidepressant drug leads through the evaluation of marine natural products with neuropsychiatric pharmacophores," Pharmacology Biochemistry and Behavior, vol. 89, no. 1, pp. 46-53, 2008.

[81] D. Tasdemir, T. S. Bugni, G. C. Mangalindan, G. P. Concepción, M. K. Harper, and C. M. Ireland, "Cytotoxic bromoindole derivatives and terpenes from the Philippine marine sponge Smenospongia sp," Zeitschrift Fur Naturforschung. C, Journal of Biosciences, vol. 57, no. 9-10, pp. 914-922, 2002.

[82] A. J. Kochanowska, K. V. Rao, S. Childress et al., "Secondary metabolites from three Florida sponges with antidepressant activity," Journal of Natural Products, vol. 71, no. 2, pp. 186-189, 2008.

[83] E. Fahy, B. C. M. Potts, D. J. Faulkner, and K. Smith, "6Bromotryptamine derivatives from the Gulf of California tunicate Didemnum candidum," Journal of Natural Products, vol. 54, no. 2, pp. 564-569, 1991.

[84] Y. Li, X. F. Li, D. S. Kim, H. D. Choi, and B. W. Son, "Indolyl alkaloid derivatives, $\mathrm{N}$ b-acetyltryptamine and oxaline from a marine-derived fungus," Archives of Pharmacal Research, vol. 26, no. 1, pp. 21-23, 2003.

[85] G. K. Oleinikova, O. I. Ivchuk, V. A. Denisenko et al., "Indolic metabolites from the new marine bacterium Roseivirga echinicomitans KMM 6058T," Chemistry of Natural Compounds, vol. 42, no. 6, pp. 713-717, 2006.

[86] G. E. Van Lear, G. O. Morton, and W. Fulmor, "New antibacterial bromoindole metabolites from the marine sponge," Tetrahedron Letters, vol. 14, no. 4, pp. 299-300, 1973.

[87] S. Aoki, Y. Ye, K. Higuchi et al., "Novel neuronal nitric oxide synthase (nNOS) selective inhibitor, aplysinopsin-type indole alkaloid, from marine sponge Hyrtios erecta," Chemical \& Pharmaceutical Bulletin, vol. 49, no. 10, pp. 1372-1374, 2001. 
[88] M. Ochi, K. Kataoka, S. Ariki, C. Iwatsuki, M. Kodama, and Y. Fukuyama, "Antioxidative bromoindole derivatives from the mid-intestinal gland of the muricid gastropod drupella fragum," Journal of Natural Products, vol. 61, no. 8, pp. 1043-1045, 1998.

[89] G. Olguin-Uribe, E. Abou-Mansour, A. Boulander, H. Débard, C. Francisco, and G. Combaut, "6-bromoindole3-carbaldehyde, from an Acinetobacter sp. bacterium associated with the ascidian Stomozoa murrayi," Journal of Chemical Ecology, vol. 23, no. 11, pp. 2507-2521, 1997.

[90] D. Davyt, W. Entz, R. Fernandez et al., "A new indole derivative from the red alga chondria atropurpurea. Isolation, structure determination, and anthelmintic activity," Journal of Natural Products, vol. 61, no. 12, pp. 1560-1563, 1998.

[91] A. Qureshi and D. J. Faulkner, "3,6-Dibromoindole, a new indole from the Palauan Ascidian Distaplia Regina," Natural Product Letters, vol. 13, no. 1, pp. 59-62, 1999.

[92] M. Bernart and W. H. Gerwick, "3-(Hydroxyacetyl)indole, a plant growth regulator from the oregon red alga Prionitis lanceolata," Phytochemistry, vol. 29, no. 12, pp. 3697-3698, 1990.

[93] J. Holenz, R. Mercè, J. L. Díaz et al., "Medicinal chemistry driven approaches toward novel and selective serotonin 5HT6Receptor ligands," Journal of Medicinal Chemistry, vol. 48, no. 6, pp. 1781-1795, 2005.

[94] M. Dukat, C. Smith, K. Herrick-Davis, M. Teitler, and R. A. Glennon, "Binding of tryptamine analogs at h5-HT1E receptors: a structure-affinity investigation," Bioorganic \& Medicinal Chemistry, vol. 12, no. 10, pp. 2545-2552, 2004.

[95] R. A. Glennon, M. Lee, J. B. Rangisetty et al., "2-substituted tryptamines: agents with Selectivity for 5-HT6Serotonin receptors," Journal of Medicinal Chemistry, vol. 43, no. 5, pp. 1011-1018, 2000.

[96] A. Canas-Rodriguez and P. R. Leeming, "N-Phenyl-2indolinones and $\mathrm{N}$-phenylindolines. New class of antidepressant agents," Journal of Medicinal Chemistry, vol. 15, no. 7, pp. 762-770, 1972.

[97] R. U. Ostrovskaya, "Principal pharmacological properties of some 2-substituted tryptamines," Bulletin of Experimental Biology and Medicine, vol. 63, no. 3, pp. 291-294, 1967.

[98] Y.-C. Xu, J. M. Schaus, C. Walker et al., "N-Methyl-5-tertbutyltryptamine: a novel, highly potent $5-\mathrm{HT}_{1 \mathrm{D}}$ receptor agonist," Journal of Medicinal Chemistry, vol. 42, no. 3, pp. 526-531, 1999.

[99] J. B. Blair, D. Marona-Lewicka, A. Kanthasamy, V. L. Lucaites, D. L. Nelson, and D. E. Nichols, "Thieno[3,2b]- and Thieno[2,3-b]pyrrole bioisosteric analogues of the hallucinogen and serotonin agonist $\mathrm{N}, \mathrm{N}$-Dimethyltryptamine," Journal of Medicinal Chemistry, vol. 42, no. 6, pp. 1106-1111, 1999.

[100] J. B. Blair, D. Kurrasch-Orbaugh, D. Marona-Lewicka et al., "Effect of ring fluorination on the pharmacology of hallucinogenic tryptamines," Journal of Medicinal Chemistry, vol. 43, no. 24, pp. 4701-4710, 2000.

[101] M. Toro-Sazo, J. Brea, M. I. Loza, M. Cimadevila, and B. K. Cassels, "5-HT2 receptor binding, functional activity and selectivity in N-benzyltryptamines," PLoS one, vol. 14, no. 1, Article ID e0209804, 2019.

[102] E. S. Vermeulen, M. van Smeden, A. W. Schmidt, J. S. Sprouse, H. V. Wikström, and C. J. Grol, "Novel 5-HT receptor inverse agonists. Synthesis and molecular modeling of arylpiperazine- and 1,2,3,4-tetrahydroisoquinoline-based arylsulfonamides," Journal of Medicinal Chemistry, vol. 47, no. 22, pp. 5451-5466, 2004.
[103] D. E. Nichols, D. H. Lloyd, M. P. Johnson, and A. J. Hoffman, "Synthesis and serotonin receptor affinities of a series of enantiomers of .alpha.-methyltryptamines: evidence for the binding conformation of tryptamines at serotonin 5-HT1B receptors," Journal of Medicinal Chemistry, vol. 31, no. 7, pp. 1406-1412, 1988.

[104] S.-W. Yang and G. A. Cordell, "Further metabolic studies of indole and sugar derivatives using the staurosporine producer Streptomyces staurosporeus," Journal of Natural Products, vol. 60, no. 3, pp. 230-235, 1997.

[105] D. J. Hayes, R. Clements, and A. J. Greenshaw, "Effects of systemic and intra-nucleus accumbens 5-HT2C receptor compounds on ventral tegmental area self-stimulation thresholds in rats," Psychopharmacology, vol. 203, no. 3, pp. 579-588, 2009. 